Jurnal Akuntansi dan Bisnis: Jurnal Program studi Akuntansi, 5 (1) Mei 2019.

ISSN 2443-3071 (Print) ISSN 2503-0337 (Online). DOI: 10.31289/iab.v5i1.1979

JURNAL AKUNTANSI DAN BISNIS

Jurnal Program Studi Akuntansi

Available online http://ojs.uma.ac.id/index.php/jurnalakundanbisnis

\title{
PENERAPAN E-FILING, E-BILLING DAN PEMERIKSAAN PAJAK TERHADAP KEPATUHAN WAJIB PAJAK ORANG PRIBADI DI KPP PRATAMA MEDAN POLONIA
}

\author{
Syamsul Bahri Arifin ${ }^{*}$, Indra Syafii \\ ${ }^{a}$ Fakultas Ekonomi Bisnis, Universitas Harapan Medan
}

Diterima Oktober 2018; Disetujui Februari 2019; Dipublikasikan Mei 2019

\begin{abstract}
Abstrak
Penelitian ini bertujuan untuk mengetahui dan menganalisis pengaruh penerapan e-filling, ebilling dan pemeriksaan pajak terhadap kepatuhan wajib pajak Orang Pribadi di KPP Pratama Medan Polonia. Sampel yang digunakan dalam penelitian ini adalah sebanyak 100 wajib pajak Orang Pribadi yang berada di wilayah KPP Pratama Medan Polonia. Penelitian ini menggunakan metode analisa kuantitatif yang menjelaskan tentang keadaan dari variabel yang diteliti dengan menggunakan data statistik. Semua indikator dari penelitian ini terlebih dahulu harus melewati uji validitas dan realibilats data yang kemudian dilakukan uji asumsi klasik serta pengujian akhirnya dilakukan uji hipotesis. Hasil penelitian ini menunjukkan bahwa terdapat pengaruh yang tidak siginifikan dari varibael bebas berupa penerapan e-filing, penerapan e-billing dan pemeriksaan pajak terhadap kepatuhan wajib pajak Orang Pribadi di KPP Pratama Medan Polonia. Kemampuan dari ketiga variabel bebas tersebut dalam menjelaskan variabel terikat adalah sangat kecil, yaitu hanya sebesar 3\% sedangkan sisanya sebesar $97 \%$ dijelaskan oleh variabel lain yang tidak dimasukkan ke dalam model penelitian ini.
\end{abstract}

Kata Kunci: Penerapan e-filing, Penerapan e-billing, Pemeriksaan Pajak dan Kepatuhan Wajib Pajak.

\begin{abstract}
This study aims to determine and analyze the effect of the application of e-filling, e-billing and tax audit on individual taxpayer compliance in Medan Polonia KPP. The sample used in this study as 100 Individual taxpayers in the Polonia Medan Primary Tax Office area. This study uses a quantitative analysis method that explains the state of the variables studied using statistical data. All indicators from this study should pass the validity test and data reality, the classical assumption test and final hypothesis test. The results of this study indicate that there are insignificant effects from free variables in the form of the application of e-filing, application of e-billing and tax audits of individual taxpayer compliance at Medan Polonia Tax Office. The ability of the three independent variables in explaining the dependent variable is very small, which is only $3 \%$ while the remaining $97 \%$ is explained by other variables were not included in this research model. Keyword: Application of e-filing, Application of e-billing, Tax Inspection and Taxpayer Compliance.
\end{abstract}

How To Cite: Arifin, S. B. \& Syafii, I. (2019) Penerapan E-Filing, E-Billing Dan Pemeriksaan Pajak Terhadap Kepatuhan Wajib Pajak Orang Pribadi Di Kpp Pratama Medan Polonia. Jurnal Akuntansi dan Bisnis: Jurnal Program Studi Akuntansi, 4 (2): 9 - 21

* email: bahrisyamsul47@yahoo.com

\section{PENDAHULUAN}

Pajak merupakan salah satu penerimaan negara yang memberikan kontribusi terbesar dalam membiayai pengeluaran termasuk pembiayaan pembangunan. Saat ini 
lebih dari 70\% dari struktur Anggaran Pendapatan dan Belanja Negara (APBN) diperoleh dari penerimaan pajak (Bawazier, F. 2018).

Untuk merealisasikan penerimaan pajak tersebut diperlukan upaya yang optimal dari Direktorat Jendral Pajak (DJP) sebagai lembaga pemerintah yang barada dibawah kementerian keuangan yang diberikan wewenang dan tangung jawab untuk merealisasikan penerimaan negara di sektor pajak. Tugas yang diemban oleh Direktorat Jenderal Pajak (DJP) beserta dengan instansi vertikal dibawah DJP, yaitu Kantor Wilayah (Kanwil) dan Kantor Pelayanan Pajak (KPP) adalah bukan pekerjaan yang mudah, disamping diperlukan peran aktif dari petugas pajak, juga diperlukan kemauan dan kesadaran dari para wajib pajak itu sendiri dalam memenuhi kewajiban perpajakannnya.

Untuk meningkatkan kepatuhan wajib pajak tersebut adalah bukan hal yang mudah seperti membalikkan telapak tangan, diperlukan upaya kreatif dari DJP berupa sosialisasi secara berkesinambungan kepada wajib pajak tentang pentingnya pajak dalam pembangunan negara sehingga kesadaran wajib pajak akan meningkat dan juga sosialisasi tentang pengetahuan perpajakan sehingga wajib pajak bisa memahami dan tidak gagal paham dalam memenuhi kewajibanperpajakan. Selain pembenahan yang dilakukan kepada wajib pajak, DJP juga telah melakukanberbagai langkah-langkah perbaikan internal, diantaranya melakukan reformasi birokrasi dan reformasi di bidang administrasi perpajakan. Salah satu reformasi dibidang administrasi perpajakan yang dilakukan oleh DJP adalah dengan melakukan modernisasi sistim administrasi perpajakan dengan memanfaatkan teknologi informasi dan komunikasi yang berbasis online, yaitu melalui sistim e-filing dan e-billing (Hasan, et, al. 2018).

Selain pemanfaatan teknologi informasi dan komunikasi di atas kepatuhan wajib pajak juga dipengaruhi oleh pemeriksaan yang dilakukan oleh fiskus atau petugas pajak kepada wajib pajak. Pelaksanaan pemeriksaan dilakukan dalam rangka menjalankan fungsi pengawasan terhadap wajib pajak yang bertujuan untuk menguji kepatuhan wajib pajak dalam memenuhi kewajiban perpajakannya dan untuk tujuan lain dalam rangka melaksanakan ketentuan peraturan perundang-undangan perpajakan (Assa, J. R., Kalangi, L., \& Pontoh, W. 2018).

Selanjutnya, beberapa penelitian yang telah dilaksanakan sebagai bahan pertimbangan seperti penelitian Husnurrosyidah dan Suhadi (2017) tentang pengaruh eFiling,e-Billing dan e-Faktur terhadap kepatuhan Pajak padaBMT Se-kabupaten Kudus dengan hasil penelitian e-filing berpengaruh terhadap kepatuhan pajak,serta e-billing berpengaruh terhadap kepatuhan pajak dan e-faktur se Kabupaten Kudus. Penelitian yang dilakukan oleh Indrianti, et. al, (2017) tentang Pengaruh Penerapan E-System perpajakan terhadap kepatuhan wajib pajak badan pada KPP Pratama Surakarta menunjukkan hasil pengujian bahwa penerapane-Registration, penerapane-Filing, penerapaneSPT,penerapan e-Billingdanpenerapan e-Faktur berpengaruh terhadap kepatuhan wajib pajak badan secara simultan, secara parsial juga menunjukkan variabel penerapan eRegistration, e-Filing, e-SPT, e-Billing,dan e- Faktur berpengaruh terhadap kepatuhan wajib pajak.

Dewi dan Supadmi (2014), meneliti tentang pengaruh pemeriksaan pajak, kesadaran, kualitas pelayanan pada tingkat kepatuhan wajib pajak badan. Hasil penelitian menghasilkan bahwa pemeriksaan pajak, kesadaran, dan kualitas pelayanan berpengaruh positif pada tingkat kepatuhan Wajib Pajak Badan di KPP Madya Denpasar. Perbedaan penelitian ini dengan penelitian sebelumnya terletak pada subjek pajak dimana penelitian terdahulu meneliti pengaruh penerapan e-filing, penerapan e-billingdan pemeriksaan pajak terhadap kepatuhan wajip pajak Badan. Penelitian lain dilakukan oleh Pratami, dkk (2017) dengan judul Pengaruh PenerapanE-System Perpajakan Terhadap Tingkat 
Kepatuhan Wajib Pajak Orang Pribadi Dalam Membayar Pajak Pada Kantor Pelayanan Pajak (KPP) Pratama Singaraja. Hasil penelitian secara parsial menunjukkan bahwa penerapan e-Registration, penerapan e-Filling, penerapan e-SPT, dan penerapan e-Billing berpengaruh positif dan signifikan terhadap tingkat kepatuhan wajib pajak orang pribadi. Sedangkan hasil penelitian secara simultan menunjukkan bahwa penerapan seluruh esystem berpengaruh positif terhadap tingkat kepatuhan wajib pajak orang pribadi. Penelitian yang dilakukan oleh Dewi (2015), tentang Pengaruh Pemeriksaan Pajak Terhadap Kepatuhan Wajib Pajak Orang Pribadi (Studi Kasus Pada KPP Pratama di Wilayah Bandung). Hasil penelitian menunjukkan bahwa pemeriksaan pajak berpengaruh terhadap kepatuhan wajib pajak orang pribadi di KPP Pratama Bandung. Perbedaan penelitian ini dengan penelitian sebelumnya adalah terletak pada lokasi wajib pajak Orang Pribadi yang berada di KPP Pratama Singaraja dan wajib pajak Orang Pribadi yang berada di KPP Pratama di Wilayah Bandung.

Berdasarkan pada penjelasan yang telah diuraikan di atas, maka tujuan dari peneliitian ini adalah untuk mengetahui apakah penerapan e-filingberpengaruh terhadap kepatuhan wajib pajak orang pribadi di KPP Pratama Medan Polonia, untuk mengetahui apakah penerapan e-billingberpengaruh terhadap kepatuhan wajib pajak orang pribadi di KPP Pratama Medan Polonia dan untuk mengetahui apakah pemeriksaan pajak berpengaruh terhadap kepatuhan wajib pajak orang pribadi di KPP Pratama Medan Polonia.

Pengertian Pajak menurut Undang Undang No. 16 Tahun 2009 tentang Ketentuan Umum Dan Tata Cara Perpajakan Pasal 1 butir 1, mendefinisikan bahwa "pajak adalah kontribusi wajib yang terutang oleh wajib pajak orang pribadi atau badan yang bersifat memaksa berdasarkan undang-undang dengan tidak mendapatkan imbalan secara langsung dan digunakan untuk keperluan negara bagi sebesar-besarnya kemakmuran rakyat". Selanjutnya menurut Soemitro dalam Resmi (2011:1) "Pajak adalah iuran rakyat kepada kas negara berdasarkan Undang - Undang (yang dapat dipaksakan) dengan tiada mendapat jasa timbal (kontraprestasi) yang langsung dapat ditunjukkan dan yang digunakan untuk membayar pengeluaran umum". Pengertian wajib pajak sebagaimana yang didefinisikan dalampasal 1 angka 2 Undang-Undang No 16 Tahun 2009 tentang KUP, adalah : "Orang pribadi atau badan, meliputi pembayar pajak, pemotong pajak, dan pemungut pajak, yang mempunyai hak dan kewajiban perpajakan sesuai dengan ketentuan peraturan perundang-undangan perpajakan". Berdasarkan pengertian tersebut wajib pajak dapat dibedakan atas wajib pajak Orang Pribadi, wajib pajak badan dan wajib pajak pemungut atau pemotong pajak yang ditunjuk oleh Pemerintah.

\section{Surat Pemberitahuan (SPT)}

Surat Pemberitahuan (SPT) sebagaimana yang tercantum dalam Pasal 1 angka 11 Undang - Undang Nomor 16 Tahun 2009 tentang KUP, adalah Surat yang oleh wajib pajak digunakan untuk melaporkan perhitungan dan/atau pembayaran pajak, objek pajak dan/atau bukan objek pajak dan/atau harta dan kewajiban, sesuai dengan ketentuan peraturan perundang - undangan perpajakan.

Fungsi SPT bagi wajib pajak penghasilan menurut Resmi (2011) adalah sebagai sarana untuk melaporkan dan mempertanggung jawabkan penghitungan jumlah pajak yang sebenarnya terutang dan untuk melaporkan tentang Pembayaran atau pelunasan pajak yang telah dilaksanakan sendiri dan/atau melalui pemotongan atau pemungutan pihak lain dalam 1 (satu) tahun pajak atau bagian tahun pajak, penghasilan yang merupakan objek pajak dan/atau bukan objek pajak, harta dan kewajiban dan pembayaran dari pemotong atau pemungut tentang pemotongan atau pemungutan pajak 
orang pribadi atau badan lain dalam 1 (satu) masa pajak sesuai dengan ketentuan dan perundang-undangan perpajakan yang berlaku.

Surat Pemberitahuan (SPT) terbagi atas dua, yaituSurat Pemberitahuan (SPT) masa, yaitu SPT yang digunakan untuk melakukan pelaporan atas pembayaran pajak bulanan dan Surat Pemberitahuan (SPT) tahunan, yaitu SPT yang digunakan untuk pelaporan tahunan. Secara umum SPT tahunan pajak penghasilan sekurang-kurangnya harus memuat jumlah peredaran bruto, jumlah penghasilan, jumlah penghasilan kena pajak, jumlah pajak yang terutang, jumlah kredit pajak, jumlah kekurangan atau kelebihan pajak serta harta dan kewajiban diluar kegiatan usaha atau pekerjaan bebas bagi wajib pajak orang pribadi.

SPT yang telah diisi dengan benar, lengkap dan jelas selanjutnya diwajibkan bagi wajib pajak untuk menyampaikan SPT tersebut ke Kantor Pelayanan Pajak atau tempat lain yang ditetapkan oleh Direktur Jenderal Pajak, yang dapat dilakukan secara langsung, melalui pos dengan bukti pengiriman suratdan cara lain, seperti melalui jasa perusahaan jasa ekspedisi atau melalui e-filling.

\section{Kepatuhan Wajib Pajak}

Kepatuhan perpajakan merupakan ketaatan, tunduk dan patuh serta melaksanakan ketentuan perpajakan. Jadi wajib pajak yang patuh adalah wajib pajak yang taat dan memenuhi serta melaksanakan kewajiban perpajakannya dengan ketentuan perundangundangan perpajakan. Menurut Pohan (2017) menyatakan bahwa "kepatuhan perpajakan dapat didefinisikan sebagai suatu keadaan dimana wajib pajak memenuhi semua kewajiban perpajakan dan melaksanakan hak perpajakannya". Menurut Pohan (2017) indikator kepatuhan wajib pajak yang dapat digunakan sebagai parameter adalah; kewajiban dalam mendaftarkan diri sebagai wajib pajak, kepatuhan dalam penyampaian surat pemberitahuan (SPT), kepatuhan dalam pelaporan yang benar (atas perhitungan dan pembayaran pajak terutang), kepatuhan dalam pembayaran (atas tunggakan pajak akhir tahun),

\section{E-Filing,}

E-filing merupakan bagian dari reformasi administrasi perpajakan yang bertujuan dalam pembuatan dan penyerahan laporan SPT kepada Direktorat Jenderal Pajak. Diterapkannya sistem e-filing diharapkan mampu memberikan kepuasan dan kenyamanan kepada wajib pajak sehingga meningkatkan kepatuhan wajib pajak. Menurut Undang-undang ketentuan PER-01/PJ/2014, e-filing adalah suatu cara penyampaian SPT tahunan secara elektronik yang dilakukan secara online dan real time melalui internet pada website Direktorat Jenderal Pajak atau penyedia layanan SPT elektronik atau application service provider (ASP).

\section{E-Biling}

E-Billing merupakan wujud dari sistem administrasi modern agar lebih efisien, ekonomis dan cepat yang dimaksudkan untuk meningkatkan kepatuhan wajib pajak.EBilling adalah cara pembayaran pajak secara elektronik dengan menggunakan kode billing (15 digit angka) yang diterbitkan melalui sistem billing pajak. E-billing mulai berlaku 1 juli 2016. Sebelum penggunaan e-billing wajib pajak harus membuat kode billing melalui customer service atau teller bank, kring pajak 1500200, sms ID billing, layanan billing di KPPatau KP2KP, internet banking maupun penyedia jasa aplikasi (ASP). Pembayaran e-billing melalui berbagai cara yaitu teller bank (kantor pos), ATM, mini ATM di KPP atau KP2KP, dan internet banking. 


\section{Pemeriksaan Pajak}

Menurut Undang-Undang No. 16 Tahun 2009 tentang Ketentuan Umum dan Tata Cara Perpajakan pasal 1 angka 25, didefinisikan pemeriksaan adalah serangkaian kegiatan menghimpun dan mengolah data, keterangan, dan/atau bukti yang dilaksanakan secara objektif dan professional berdasarkan suatu standard pemeriksaan.

Tugas pemeriksaan dilakukan oleh Direktorat Jendral Pajak dalam rangka melakukan pengawasan kepatuhan pemenuhan kewajiban perpajakan wajib pajak berwenang melakukan pemeriksaan untuk menguji kepatuhan pemenuhan kewajiban perpajakan wajib pajak dan tujuan lain dalam rangka melaksanakan ketentuan peraturan perundang-undangan perpajakan.

Pelaksanaan pemeriksaan dalam rangka menguji kepatuhan pemenuhan kewajiban perpajakan wajib pajak dilakukan dengan menelusuri kebenaran dari Surat Pemberitahuan (SPT), pembukuan dan pencatatan, dan pemenuhan kewajiban perpajakan lainnya dibandingkan dengan keadaan atau kegiatan usaha sebenarnya dari wajib pajak.

\section{METODE PENELITIAN}

Jenis penelitian yang akan digunakan dalam penelitian ini adalah asosiatif, yaitu penelitian yang dilakukan dengan maksud untuk mengetahui hubungan sebab akibat atau pengaruh antara dua atau lebih variabel (Sugiyono, 2014). Populasi dalam penelitian ini adalah wajib pajak Orang Pribadi yang berada di wilayah KPP Pratama Medan Polonia yang berjumlah lebih kurang sebanyak 50.427 wajib pajak. Tehnik pengambilan sampel dilakukan dengan menggunakan rumus Slovin, dimana diperoleh jumlah sampel dari populasi yang ada sebanyak 100 orang wajib pajak.

Tehnik pengumpulan data dilakukan dengan membagi kuesioner kepada responden dalam sampel yang telah ditentukan jumlahnya. Daftar pertanyaan yang diajukan meliputi pertanyaan-pertanyaan yang berkaitan dengan variabel yang akan diteliti yaitu variabel penerapan e-filing (X1), penerapan e-billing, pemeriksaan pajak (X3) dan variabel tingkat kepatuhan (Y). Tehnik analisa data yang dilakukan sebelumnya adalah seluruh instrumen penelitian harus terlebih dahulu lolos uji validitas dan reliabilitas, kemudian lolos uji asumsi klasik berupa uji normalitas, uji multikolinearitas dan uji heteroskedastisitas.

Selanjutnya untuk mengetahui hubungan yang terjadi antar variabel digunakan analisa regresi berganda yang kemudian dilanjutkan dengan pengujian hipotesi, yaitu uji $\mathrm{t}$, uji f dan uji koefisien determinasi (uji R). Data tabulasi dari jawaban responden yang diperoleh dan diolah menggunakan alat uji statistika.

\section{HASIL DAN PEMBAHASAN}

\section{Uji Validitas}

Pada tabel 1.1 berikut ini diperoleh hasil pengujian validitas data dari jawaban responden, sebagai berikut: 
Arifin, S. B. \& Syafii, I. (2019) Penerapan E-Filing, E-Billing Dan Pemeriksaan Pajak Terhadap Kepatuhan Wajib Pajak Orang Pribadi Di Kpp Pratama Medan.....

Tabel 1.1 Uji Validitas

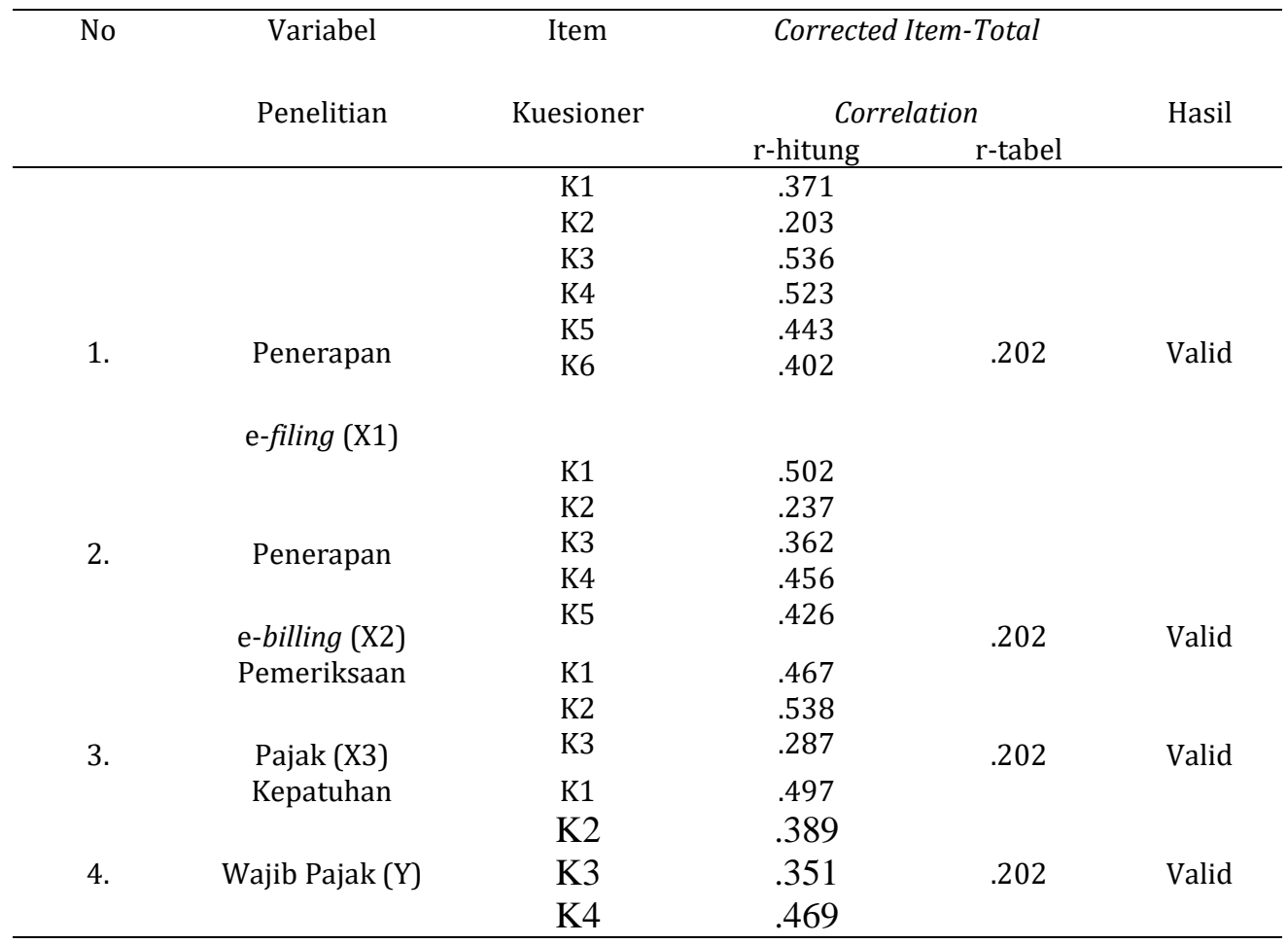

Pada Tabel 1 di atas diketahui bahwa hasil pengujian validitas menunjukkan bahwa untuk seluruh item kuesioner yang terdapat pada variabel penerapan e-filing (X1),penerapan ebilling (X2), pemeriksaan pajak (X3) dan kepatuhan wajib pajak (Y) mempunyai nilai Corrected Item-Total Correlation rhitung $>\mathrm{r}_{\text {tabel }}(0,202)$, sehingga dapat disimpulkan bahwa seluruh item kuesioner dapat dinyatakan valid dan layak untuk digunakan dalam penelitian.

\section{Uji Reliabilitas}

Pada Tabel 1.2 berikut ini diperoleh hasil pengujian reliabilitas dari pengolahan hasil tabulasi jawaban responden, sebagai berikut:

\begin{tabular}{ccccc}
\multicolumn{5}{c}{ Tabel 1.2 Uji Reliabilitas } \\
\hline & \multicolumn{2}{c}{ Reliability Statistic } \\
No & Variabel & Cronbach's Alpha & Nilai Standard & \\
\hline 1. & Penerapan e-filing & 0,682 & 0,6 \\
2. & Penerapan e-biling & 0,632 & 0,6 \\
3. & Pemeriksaan Pajak & 0,611 & 0,6 & \\
4. & Kepatuhan Wajib Pajak & 0,643 & 0,6 & \\
& & & & Reliabel \\
\hline
\end{tabular}

Pada table 1.2 di atas diketahui bahwa nilai Croncbach's Alpha untuk variabel penerapan e-filing (X1),penerapan e-billing (X2), pemeriksaan pajak (X3) dan kepatuhan wajib pajak (Y) mempunyai nilai Cronbach's Alpha> 0,6 , sehingga hasil penelitian ini dapat disimpulkan bahwa variabel penelitian digunakan dapat dinyatakan reliabel, berarti seluruh jawaban yang diberikan oleh responden atas variabel penelitian digunakan mempunyai konsistensi yang baik. 


\section{Regresi Linear Berganda}

Berikut ini dapat disajikan hasil pengujian untuk persamaan regresi linear berganda dari pengolahan hasil tabulasi jawaban responden, sebagai berikut:

Tabel 1.3 Regresi Linier Berganda

\begin{tabular}{cccc}
\hline & \multicolumn{2}{c}{ Unstandarddized Coefficients } & $\begin{array}{c}\text { Standarddized } \\
\text { Coefficients } \\
\text { Beta }\end{array}$ \\
\hline Model & $\mathrm{B}$ & Std.Error & .278 \\
Penerapan e-filing & 10.192 & .081 & .181 \\
Penerapan e-biling & .143 & .088 & .022 \\
Pemeriksaan Pajak & .020 & .113 & .126 \\
\hline
\end{tabular}

Berdasarkan tabel 1.3 diperoleh regresi linear berganda yaitu $Y=10,192+0,143 \mathrm{X}_{1}$ $+0,020 X_{2}+0,137 X_{3}$, ini menunjukkan bahwa nilai konstanta (a) mempunyai nilai sebesar 10,192 dan positif, artinya apabila diasumsikan variabel penerapan e-filing, penerapan e-billing dan pemeriksaan pajak nilainyanol, maka nilai dari variabel kepatuhan wajib pajak sebesar 10,192. Variabel penerapan e-filing mempunyai nilai koefisien regresi sebesar 0,143 dan arah positif, hal ini berartiapabila penerapan efilingditingkatkan sebesar 1 satuan maka kepatuhan wajib pajak akan meningkat sebesar 0,143 dengan asumsi nilai koefisien regresi pada variabel penerapan e-billing dan pemeriksaan pajak adalah bernilai nol. Variabel penerapan e-billing mempunyai nilai koefisien regresi sebesar 0,020 dan arah positif, hal ini berarti apabila penerapan ebillingditingkatkan 1 satuan kepatuhan wajib pajak akan meningkat sebesar 0,020 dengan asumsi nilai koefisien regresi pada variabel penerapan e-filing dan pemeriksaan pajak adalah bernilai nol. Variabel pemeriksaan pajak mempunyai nilai koefisien regresi yaitu sebesar 0,137 dan arah positif, hal ini berartiapabila variabel pemeriksaa pajak ditingkatkan 1 satuan maka kepatuhan wajib pajak akan meningkat sebesar sebesar 0,137 dengan asumsi nilai koefisien regresi pada variabel penerapan e-filing dan e-billingadalah bernilai nol.

\section{Uji Normalitas}

Berikut ini dapat disajikan hasil pengujian normalitas dengan metode KolmogorovSmirnov Test dari pengolahan hasil tabulasi jawaban responden, sebagai berikut:

Tabel 1.4 hasil Uji Kolmogorov-Smirnov Test

\begin{tabular}{ccr}
\hline & & \multicolumn{1}{c}{ Unstandardized Residual } \\
\hline \multirow{2}{*}{ Normal Parameters $^{a}$} & & 100 \\
& Mean & .0000000 \\
Most Extreme Differences & Std. Deviation & .86650172 \\
& Absolute & .092 \\
& Positive & .092 \\
& Negative & -.054 \\
Kolmogorov-Smirnov Z & & .916 \\
Asymp. Sig. (2-tailed) & & .200 \\
\hline
\end{tabular}

Pada Tabel 1.4 menunjukkan bahwa diperoleh nilai Asymp. Sig. (2-tailed)sebesar 0,200 , oleh karena nilai signifikansi 0,200>0,05 maka dapat diambil kesimpulkan bahwa data penelitian yang digunakan menunjukkan nilai residual berdistribusi secara normal pada model regresi. 
Arifin, S. B. \& Syafii, I. (2019) Penerapan E-Filing, E-Billing Dan Pemeriksaan Pajak Terhadap Kepatuhan Wajib Pajak Orang Pribadi Di Kpp Pratama Medan.....

\section{Uji Multikolinearitas}

Berikut ini dapat disajikan hasil pengujian multikolinearitas dari pengolahan hasil tabulasi jawaban responden, sebagai berikut:

Tabel 1.5 Hasil Uji Multikolinearitas

\begin{tabular}{lcc}
\hline Model & \multicolumn{2}{c}{ Collinearity Statistics } \\
\hline (Constant) & Tolerance & VIF \\
Penerapan e-filing & .921 & 1.086 \\
Penerapan e-biling & .994 & 1.006 \\
Pemeriksaan Pajak & .917 & 1.090 \\
\hline Dependent Variable : Kepatuhan Wajib Pajak
\end{tabular}

Berdasarkan hasil uji multikolineairitas pada tabel 5 terlihat bahwa nilai Tolerance dan VIF untuk variabel independen, yaitu Variabel penerapan e-filing mempunyai nilai Tolerance sebesar 0,921 dan nilai VIF sebesar 1.086. Variabel penerapan e-billing mempunyai nilai Tolerance sebesar 0,994 dan nilai VIF sebesar 1.006. Variabel pemeriksaan pajak mempunyai nilai Tolerance sebesar 0,917 dan nilai VIF sebesar 1.090. Dari hasil pengujian multikolinearitas pada variabel independen di atas, dapat disimpulkan semua variabel independen yaitu penerapan e-filing, penerapan e-billing dan pemeriksaan pajak mempunyai nilai Tolerance $>0,1$ dan nilai VIF $<10$ sehingga dapat disampaikan model regresi menunjukkan tidak terjadi gejala multikolinearitas (antar variabel bebas tidak berkorelasi).

\section{ji Hipotesis}

\section{Uji Parsial}

Berikut ini dapat disajikan hasil pengujian parsial dari pengolahan hasil tabulasi jawaban responden, sebagai berikut:

\begin{tabular}{lcc}
\multicolumn{3}{c}{ Tabel 1.6 Hasil Uji Partial } \\
\hline Model & $\mathrm{t}$ & Sig \\
\hline (Constant) & 3.661 & .000 \\
Penerapan e-filing & 1.757 & .082 \\
Penerapan e-billing & .223 & .824 \\
& & .227 \\
Pemeriksaan Pajak & 1.217 &
\end{tabular}

Pada Tabel 1.6 di atas menunjukkan hasil bahwa nilai koefisien dan signifikansi untuk variabel independen dapat dijelaskan bahwa Variabel penerapan e-filing mempunyai nilai koefisien thitung sebesar 1.757 dengan signifikan 0,082. Variabel penerapan e-billing mempunyai nilai koefisien thitung sebesar .223 dengan signifikan .824.Variabel pemeriksaan pajak mempunyai nilai koefisien thitung yaitu sebesar 1.217 dengan signifikan .227.

Pada penelitian dilakukan diketahui bahwa jumlah sampel penelitian sebanyak $\mathrm{n}=$ 100, sehingga diperoleh $n-4=100-4=96$ maka nilai koefisien $t_{\text {tabel }}=1,985$ pada signifikan 0,05. Dengan demikian, dari hasil pengujian parsial dapat disimpulkan antara lain Variabel penerapan e-filing berpengaruh tidak signifikan terhadap kepatuhan wajib 
pajak pada KPP Pratama Medan Polonia, hal ini dapat terlihat bahwa nilai koefisien thitung $<$ ttabel, yaitu $1.757<1,985$ pada signifikan 0,082> 0,05. Dengan demikian, dapat disimpulkan bahwa hipotesis penelitian dapat dinyatakan bahwa $\mathrm{H}_{1}$ ditolak Hoditerima. Variabel penerapan e-biling berpengaruh tidak signifikan terhadap kepatuhan wajib pajak pada KPP Pratama Medan Polonia, hal ini terlihat dari nilai koefisien $t_{\text {hitung }}<t_{\text {tabel, }}$ yaitu $.223<1,985$ pada signifikan 0,824>0,05. Dengan demikian, dapat disimpulkan bahwa hipotesis penelitian dapat dinyatakan bahwa $\mathrm{H}_{2}$ ditolak dan $\mathrm{H}_{0}$ diterima. Variabel pemeriksaan pajak tidak berpengaruh tidaksignifikan terhadap kepatuhan wajib pajak pada KPP Pratama Medan Polonia, hal ini terlihat dari nilai koefisien $t_{\text {hitung }}<t_{\text {tabel, }}$ yaitu $1,217<1,985$ pada signifikan 0,227 > 0,05. Dengan demikian, dapat dikemukakan bahwa hipotesis penelitian dapat dinyatakan bahwa $\mathrm{H}_{3}$ ditolak dan $\mathrm{H}_{0}$ diterima.

\section{Koefisien Determinasi}

Berikut ini disajikan hasil uji determinasi dari hasil pengolahan tabulasi jawabanresponden, sebagai berikut:

Tabel 7 Hasil Koefisien Determinasi $\left(\mathrm{R}^{2}\right)$

\begin{tabular}{crrrr}
\hline Model & $\mathrm{R}$ & R Square & $\begin{array}{c}\text { Adjusted } \\
\text { Square }\end{array}$ & $\begin{array}{c}\text { Std. Error of the } \\
\text { Estimate }\end{array}$ \\
\hline 1 & $.250_{\mathrm{a}}$ & .062 & .033 & 1,88735 \\
\hline
\end{tabular}

Pada tabel 7 di peroleh nilai koefisien determinasi Adjusted R Square adalah kecil sekali yaitu sebesar 0.033, hal ini berarti bahwa kemampuan variabel penerapan e-filing, penerapan e-billing dan pemeriksaan pajak dalam menjelaskan kepatuhan wajib pajak di KPP pratama Medan Polonia adalah hanya sebesar 3\% saja sedangkan sisanya sebesar 97\% dapat dijelaskan oleh variabel lain yang tidak dimasukkan dalam penelitian ini, seperti pengetahuan perpajakan wajib pajak, pelayanan fiskus, sanksi perpajakan, dan sebagainya.

\section{Pengaruh Penerapan e-filing terhadap Kepatuhan Wajib Pajak di KPP Pratama Medan Polonia}

Berdasarkan hasil pengujian statistik yang dilakukan menunjukkan bahwa secara parsial penerapan e-filing berpengaruh tidak signifikan terhadap kepatuhan wajib pajak pada KPP Pratama Medan Polonia. Hasil ini dapat ditunjukkan dari nilai signifikansi sebesar 0,082>0,05. Berdasarkan pembahasan yang sudah dilakukan, maka dapat disimpulkan bahwa penerapan e-filing tidak berpengaruh terhadap kepatuhan Wajib Pajak dalam penyampaian SPT Tahunan Orang Pribadi pada KPP Pratama Medan Polonia.

Meskipun pihak Direktorat Jendral Pajak (DJP) telah melakukan reformasi di bidang modernisasi administrasi perpajakan yaitu dengan menyampaikan SPT tahunan Orang Pribadi melalui e-filing dengan maksud dan tujuan agar wajib pajak dapat lebih nyaman dan mudah menyampaikan SPT dalam rangka memenuhi kewajiban perpajakannnya, namun tetap saja keinginan wajib pajak untuk menyampaikan SPT tahunan Orang Pribadi di KPP Pratama Medan Polonia belumtercapai sesuai dengan yang diharapkan.

Hal ini terlihat dari data yang diperoleh dari KPP Pratama Medan Polonia bahwa pertumbuhan wajib pajak orang pribadi yang menyampaikan SPT tahunan pada 3 tahun terakhir setiap tahunnya cenderung menurun, yaitu: 17,31\% (2014), 16,47\% (2015) dan 1\% (2016), sedangkan pertumbuhan wajib pajak orang pribadi yang terdaftar di KPP Pratama Medan Polonia pada 3 tahun terakhir menunjukkan kenaikan, yaitu 4,\% (2014), 4\% (2015) dan 6\% (2016) hal ini berarti bahwa kenaikan jumlah wajib pajak orang pribadi yang terdaftar berbanding terbalik dengan jumlah wajib pajak orang pribadi yang 
wajib SPT yang seharusnya berbanding lurus. Keadaan ini mencerminkan bahwa masih ada kecenderungan dari wajib pajak orang pribadi di KPP Pratama Medan Polonia yang tidak melaporkan SPT tahunan sebagai wujud kepatuhan wajib pajak dalam memenuhi kewajiban perpajakannya.

Diketahui bahwa wajib pajak Orang Pribadi yang menggunakan e-filing dalam melaporkan SPT tahunannya terlihat dalam 3 tahun terakhir setiap tahunnya semakin meningkat sedangkan wajib pajak yang melaporkan SPT secara manual cendrung menurun, yaitu: pada tahun 2014 dari 32.780 wajib pajak orang pribadi yang menyampaikan SPT tahunannya ada sebanyak 3.401 orang menggunakan e-filingatau sebesar $10 \%$ dari total wajib pajak Orang Pribadi yang melaporkan SPT, sedangkan sisanya sebanyak 29.379 orang atau sama dengan 90\% dari total Orang Pribadi yang melaporkan SPT menggunakan manual.

Pada tahun 2015 dari 39.243 wajib pajak orang pribadi yang menyampaikan SPT tahunannya ada sebanyak 11.886 Orang Pribadi menggunakan e-filing atau sebesar 30\%dan sebanyak 27.357 Orang Pribadi menggunakan manual atau sebesar 70\%, dan pada tahun 2016 dari 39.637 wajib pajak orang pribadi yang menyampaikan SPT tahunannya sebanyak 31.885 wajib pajak Orang Pribadi menggunakan e-filing atau sebesar $80 \%$ dan sebanyak 7.752 wajib pajak Orang Pribadi menggunakan manual atau sebesar 20\%. Kenaikan penggunaan penyampaian SEPERTI tahunan Orang Pribadi tersebut tidak diikuti dengan pertumbuhan wajib pajak Orang Pribadi yang melaporkan SPT tahunan yang diketahui cenferung menurun, yaitu 17,31\% (2014), 16,46\% (2015) dan 1\% (2016).

Dari data di atas dapat disimpulkan bahwa penerapan e-filing di KPP Pratama Medan Polonia tidak mempunyai pengaruh yang signifikan dengan peningkatan wajib pajak orang pribadi yang melapor SPT tahunan. Dengan perkataan lain e-filing belum berhasil meningkatkan kepatuhan wajib pajak dalam memenuhi kewajiban perpajakannya di KPP Pratama Medan Polonia, akan tetapi penerapan e-filing hanya dapat memberikan kemudahan bagi wajib pajak orang pribadi yang pada tahun sebelumnya telah melaporkan SPT tahunan dengan cara manual beralih kepada penyampaian SPT dengan menggunakan e-filing sehingga tujuan Direktorat Jenderal Pajak (DJP) melakukan reformasi perpajakan di bidang administrasi perpajakan di KPP Pratama Medan Polonia belum dapat tercapaisebagaimana yang diharapkan, yaitu e-filing diharapkan dapat meningkatkan kepatuhan wajib pajak orang pribadi utnuk menyampaikan laporan SPT tahunan, dimana penyampaian SPT tahunan merupakan sebagai salah satu indikator dari .pengukuran ratio kepatuhan sebagaimana yang telah di uraikan di atas.

Hasil penelitian ini tidak sejalan dengan penelitian-penelitian yang telah dilakukan oleh peneliti sebelumnya, diantaranya penelitian yang dilakukan oleh Hussnurrosyidah dan Suhadi (2016) dimana penelitian tersebut menunjukkan bahwa penerapan E-Filing berpengaruh positip dan signifikan terhadap kepatuhan wajib pajak. Hasil yang berbeda juga ditunjukkan pada penelitian yang dilakukan oleh Pratami, dkk (2017) yang menunjukkan hasil bahwa E-Filing berpengaruh positip dan signifikan terhadap kepatuhan wajib pajak orang pribadi pada KPP Pratama Singaraja. Dari kedua hasil penelitian terdahulu dapat disimpulkan bahwapenerapan e-filingdapat meningkatkan kepatuhan wajib pajak.

\section{Pengaruh penerapan e-billing terhadap kepatuhan wajib pajak orang pribadi di KPP Pratama} Medan Polonia. 
Berdasarkan hasil pengujian statistik yang dilakukan menunjukkan bahwa secara parsial penerapan e-billing berpengaruh tidak signifikan terhadap kepatuhan wajib pajak pada KPP Pratama Medan Polonia. Hasil ini dapat ditunjukkan dari nilai signifikansi sebesar 0,824>0,05. Berdasarkan pembahasan yang sudah dilakukan, maka dapat disimpulkan bahwa penerapan e-billing tidak berpengaruh terhadap kepatuhan Wajib Pajak dalam penyampaian SPT Tahunan Orang pribadi pada KPP Pratama Medan Polonia.

Hasil penelitian ini sejalan dengan data yang diperoleh dari data wajib pajak orang pribadi di KPP Pratama Medan Polonia yang melakukan pembayaran pajak dengan ebilling.Realisasi SPT tahunan OP dengan status SPT kurang bayar (KB) pada 3 tahun terakhir menunjukkan bahwa hasil pembayaran pajak kurang bayar masih belum memadai sebagaimana yang diharapkan, hal ini terlihat dari wajib pajak orang pribadi yang melakukan pembayaran pajak sebanyak 4.263 orang pada tahun 2014, tahun 2015 mengalami penurunan drastis, yaitu hanya sebanyak 2.375 orang dan pada tahun 2017 naik menjadi sebanyak 2.545 orang atau pertumbuhannya hanya naik sebesar $2,5 \%$ di tahun 2016, jika dibandingkan dengan pertumbuhan wajib pajak terdaftar pada tahun 2016 sebesar 6\% maka pertumbuhan wajib pajak yang melakukan pembayaran pajak tidak sebanding dengan pertumbuhan wajib pajak terdaftar. Selanjutnya jika dibandingkan dengan tingkat pertumbuhan wajib pajak orang pribadi yang membayar pajak di tahun 2014 mengalami penurunan yang cukup sigifikan yaitu sebesar $40 \%$. Dari kedua indikator ini dapat disimpulkan bahwa kecenderungan wajib pajak di KPP Pratama Medan Polonia untuk sadar dan patuh membayar pajak dalam rangka memenuhi kewajiban perpajaknnya masih kurang dari yang diharapkan.

Selanjutnya dari data di atas dapat dilihat bahwa wajib pajak orang pribadi yang menggunakan e-billing dalam melakukan pembayaran pajak kurang bayar dalam 3 tahun terakhir setiap tahunnya semakin meningkat, sedangkan wajib pajak yang melakukan pembayaran pajak secara manual cendrung menurun. Pada tahun 2014 dari 6.892 wajib pajak orang pribadi yang melakukan pembayaran pajakkurang bayar sebanyak 84 orang wjib pajak Orang Pribadi menggunakan e-billing atau sebesar 1\%, dan sebanyak 6.808 wajib pajak Orang Pribadi menggunakan manual atau sebesar 99\%. Pada tahun 2015 dari 7.841 wajib pajak orang pribadi yang melakukan pembayaran pajak kurang bayar sebanyak 415 orang wajib pajak Orang Pribadi menggunakan e-billing atau sebesar 5\% dan sisanya7.426 wajib pajak Orang Pribadi menggunakan manual atau sebesar 95\%. Selanjutnya pada tahun 2016 dari 10.677 wajib pajak orang pribadi yang melakukan pembayaran pajak kurang bayar sebanyak 9.861 wajib pajak Orang Pribadi menggunakan e-billing atau sebesar 92\% dan sisanya sebanyak 816 wajib pajak Orang Pribadi menggunakan manual atau sebesar $8 \%$.

Dari gambaran di atas dapat disimpulkan bahwa kecenderungan penggunaan ebilling di KPP Pratama Medan Polonia meningkat tajam setiap tahunnnya akan tetapi jika dibandingkan dengan data wajib pajak orang pribadi yang melakukan realisasi pembayaran pajak kurang bayar pada 3 tahun terakhir seperti yang telah diuraikan di atas cenderung turun, yaitu 4.263 wajib pajak Orang Pribadi pada tahun 2014, 2.375 wajib pajak Orang Pribadi pada tahun 2015 dan 2.545 wajib pajak Orang Pribadi pada tahun 2016, bahkan jika dibandingkan pertumbuhan realisasi orang pribadi yang membayar pajak kurang bayar tahun 2015 dibanding tahun 2014 terdapat penurunan yang cukup signifikan yaitu 44\% dan pada tahun 2016 turun sebesar 40\%. Hal ini berarti bahwa penerapan e-billing tidak memberikan pengaruh yang signifikan terhadap kepatuhan wajib pajak orang pribadi di KPP Pratama Medan Polonia.Penerapan e-billing tidak berhasil meningkatkan hasil penerimaan pajak di KPP Pratama Medan Polonia, akan tetapi penerapan e-billing hanya dapat memberikan kemudahan bagi wajib pajak orang 
pribadi yang pada tahun sebelumnya telah melakukan pembayaran pajak kurang bayar dengan cara manual beralih kepada pembayaran pajak kurang bayar dengan menggunakan e-billing, sehingga tujuan Direktorat Jenderal Pajak (DJP) melakukan reformasi perpajakan di bidang administrasi perpajakan di KPP Pratama Medan Polonia belum dapat tercapai sebagaimana yang diharapkan, yaitu e-billing diharapkan dapat meningkatkan kepatuhan wajib pajak orang pribadi sebagaimana yang telah di uraikan di atas. Hasil penelitian ini juga tidak sejalan dengan penelitian-penelitian yang telah dilakukan oleh peneliti sebelumnya, diantaranya penelitian yang dilakukan oleh Hussnurrosyidah dan Suhadi (2016) dimana penelitian tersebut menunjukkan bahwa penerapan e-billing berpengaruh positip dan signifikan terhadap kepatuhan wajib pajak. Hasil yang berbeda juga ditunjukkan pada penelitian yang dilakukan oleh Pratami, dkk (2017) yang menunjukkan hasil bahwa e-billing berpengaruh positip dan signifikan terhadap kepatuhan wajib pajak orang pribadi pada KPP Pratama Singaraja. Dari kedua hasil penelitian sebelumnya ini dapat disimpulkan bahwa penerapan e-billing akan mengakibatkan kepatuhan wajib pajak meningkat.

\section{Pengaruh pemeriksaan pajak terhadap kepatuhan wajib pajak Orang Pribadi di KPP Pratama Medan Polonia.}

Berdasarkan hasil pengujian statistik di atas menunjukkan bahwa secara parsial pemeriksaan pajak berpengaruh tidak signifikan terhadap kepatuhan wajib pajak pada KPP Pratama Medan Polonia. Hasil ini dapat ditunjukkan dari nilai signifikansi sebesar $0,227>0,05$. Berdasarkan pembahasan yang sudah dilakukan, maka dapat disimpulkan bahwa pemeriksaan pajak tidak berpengaruh terhadap kepatuhan Wajib Pajak dalam penyampaian SPT Tahunan Orang pribadi pada KPP Pratama Medan Polonia.

Hasil penelitian ini sejalan dengan data yang diperoleh dari jumlah wajib pajak orang pribadi di KPP Pratama Medan Polonia yang dilakukan pemeriksaan dalam 3 tahun terakhir menunjukkan bahwa wajib pajak yang dilakukan pemeriksaan tidak dibandingkan dengan wajib pajak yang masuk dalam kriteria pemeriksaan. Dari data di atas dapat dilihat bahwa wajib pajak yang diperiksa pada tahun 2014 dan 2015 sebanyak 27 wajib pajak Orang Pribadi dan pada tahun 2016 sebanyak 138 wajib pajak Orang Pribadi,sedangkan wajib pajak Orang Pribadi yang termasuk dalam kriteria pemeriksaan pada tahun 2014 sebanyak 11.848 wajib pajak Orang Pribadi, tahun 2015 sebanyal 13.903 wajib pajak Orang Pribadi dan pada tahun 2016 sebanyak 7.783 wajib pajak Orang Pribadi. Meskipun pada tahun 2016 menunjukkan bahwa wajib pajak Orang Pribadi yang diperiksa mengalami peningkatan dan wajib pajak Orang Pribadi yang masuk dalam kriteria pemeriksaan menunjukkan penurunan, akan tetapi wajib pajak Orang Pribadi yang dilakukan pemeriksaan relatif sangat sedikit sekali, yaitu hanya sebesar 1,8\%. Hal ini berarti pada tahun 2016 dari 7.783 wajib Pajak Orang Pribadi yang termasuk kriteria pemeriksaan, hanya 138 wajib pajak yang dilakukan pemeriksaan.

Rendahnya tingkat persentase pemeriksaan yang dilakukan oleh KPP Pratama Medan Polonia tidak akan menimbulkan efek jera bagi wajib pajak Orang Pribadi yang tidak memenuhi kewajiban perpajakannya. Hal ini merupakan salah satu faktor penyebab bahwa pemeriksaan pajak yang dilakukan oleh KPP Pratama Medan Polonia tidak berpengaruh positip dan signifikan terhadap kepatuhan wajib pajak.

Hasil penelitian ini juga tidak sejalan dengan penelitian-penelitian yang telah dilakukan oleh kedua peneliti sebelumnya, yaitu yang dilakukan oleh Dewi (2015). Hasil penelitian menghasilkan bahwa Pemeriksaan Pajak berpengaruh terhadap Kepatuhan Wajib Pajak Orang Pribadi di KPP Pratama Bandung. Dan penelitian yang dilakukan oleh Anjarini, dkk (2012)yang memberikan hasil bahwa pemeriksaan pajak berpengaruh 
positip dan signifikan terhadap kepatuhan wajib pajak Orang Pribadi pada KPP Pratama Jakarta. Dari Hasil kedua penelitian sebelumnya ini dapat disimpulkan bahwa semakin tinggi pemeriksaan pajak terhadap wajip pajak Orang Pribadi maka akan semakin meningkat kepatuhan wajib pajak.

\section{SIMPULAN}

Berdasarkan hasil pengolahan data dan pembahasan beberapa kesimpulan dapat diambil yakni secara parsial menunjukkan bahwa penerapan e-filing tidak berpengaruh signifikan terhadap kepatuhan wajib pajak Orang Pribadi di KPP Pratama Medan Polonia. Kemudian secara parsial menunjukkan bahwa penerapan e-billing tidak berpengaruh signifikan terhadap kepatuhan wajib pajak Orang Pribadi di KPP Pratama Medan Polonia. secara parsial menunjukkan bahwa pemeriksaan pajak tidak berpengaruh signifikan terhadap kepatuhan wajib pajak Orang Pribadi di KPP Pratama Medan Polonia. Dan pada koefisien determinasi menunjukkan penerapan e-filing, penerapan e-billing dan pemeriksaan pajak mempunyai hubungan yang sangat lemah terhadap kepatuhan wajib pajak pada KPP Pratama Medan Polonia. Nilai koefisien adjusted R square (R2) sebesar 0,033 menunjukkan bahwa kepatuhan wajib pajak di KPP Pratama Medan Polonia mampu dijelaskan oleh variabel penerapan e-filing, penerapan e-billing dan pemeriksaan pajak sebesar 3\% saja dan sisanya 97\% dijelaskan oleh variabel lainnya tidak diteliti.

\section{DAFTAR PUSTAKA}

Anajarini, Kusujarwati, Prasetyo, Buntoro Heri, Irani, Lia Dahlia (2012), Analisi Pelaksanaan Pemeriksaan Pajak Dalam Meningkatkan Kepatuhan Wajib Pajak Orang Pribadi Pada KPP Pratama Jakarta Sawah Besar Satu. Jurnal Akuntansi Perpajakan

Assa, J. R., Kalangi, L., \& Pontoh, W. (2018). Pengaruh Pemeriksaan Pajak Dan Sanksi Perpajakan Terhadap Kepatuhan Wajib Pajak Pada Kantor Pelayanan Pajak Pratama Manado. Jurnal Riset Akuntansi Going Concern, 13(04).

Dewi, Cahaya Shinta dan Supadmi, Ni Luh (2014), Pengaruh Pemeriksaan Pajak, Kesadaran, Kualitas Pelayanan Pada Tingkat Kepatuhan Wajib Pajak Badan, e-Jurnal akuntansi Universitas Udayana, 9.2 (2014)

Dewi, Armelita Intan Hera(2015), Pengaruh Pemeriksaan Pajak Terhadap Kepatuhan Wajib Pajak Orang Pribadi (Studi Kasus Pada KPP Pratama Di Wilayah Bandung), Skripsi Sarjana Ekonomi Program Stui Akuntansi, Fakultas Ekonomi Universitas Widyatama

Direktorat Jendral Pajak (2016), Laporan Kinerja (Lakin) 2016

Hasan, F. A., Afifudin, A., \& Junaidi, J. (2018). Pengaruh Penerapan Sistem Administrasi E-Registration Dan E-Filing Terhadap Tingkat Kepatuhan Wajib Pajak (Studi Kasus pada Wajib Pajak Orang Pribadi di Kantor Pelayanan Pajak Pratama Sidoarjo Utara). Jurnal Riset Akuntansi, 7(01).

Husnurrosyidah, dan Suhadi (2017), Pengaruh e-Filing, e-Billing dan e-Faktur Terhadap Kepatuhan Pajak Pada BMT se-Kabupaten Kudus. Jurnal Analisa Akuntansi dan Perpajakan, Volume 1, Nomor 1, Maret 2017, Hal 97 - 106

Indrianti, Irma, Suhendro dan Masitoh, Endang (2017), Pengaruh Penerapan E-System Perpajakan Terhadap Kepatuhan Wajib Pajak Badan (Studi Kasus Di KPP Pratama Surakarta), Seminar Jenaco

Pohan, A, Chairil (2017), Pengantar Perpajakan :Teori dan Konsep Hukum Pajak, Mitra Wacana Media, Jakarta.

Peraturan Direktur Jenderal Pajak Nomor :PER-01/PJ/2014 tentang E-filing

Pratami, Luh Putu Kania, Sulindawati,Ni Luh Gede Erni, Arie, Made (2017), Pengaruh, PenerapanE-System Perpajakan Terhadap Tingkat Kepatuhan Wajib Pajak Orang Pribadi Dalam Membayar Pajak Pada Kantor Pelayanan Pajak (KPP) Pratama Singaraja, e-Journal S1 Ak, Universitas Pendidikan Ganesha Jurusan Akuntansi Program S1, Volume 7, No 1, Tahun 2017

Resmi, Siti (2011), Perpajakan Teori dan Kasus, Salemba Empat, Jakarta

Sugiono (2014),Metode Penelitian Kuantitatif, Kualitatif, dan R\&D. Alfabeta. Bandung.

Undang-Undang No. 16 Tahun 2009 tentang Ketentuan Umum dan Tata Cara Perpajakan. 